\title{
NOTES ON COLURA CRENULATA (LEJEUNEACEAE, MARCHANTIOPHYTA), A NEW RECORD FOR THAILAND, WITH A SPOROPHYTE DESCRIPTION
}

\author{
Jiroat Sangrattanaprasert, Sahut Chantanaorrapint ${ }^{1}$ \& Rui-Liang Zhu
}

\begin{abstract}
Colura crenulata Grolle (Lejeuneaceae), a rare and poorly known species from Papua New Guinea, Sumatra and Borneo, was newly discovered in tropical montane forests in southern Thailand. It is characterized by its acutely mamillose lobule sac and perianth; apical crest of the lobule sac consisting of 1-5 cells; large valve composed of 18-21 hyaline margin cells and 20-29 median cells, with a single median basal cell; and nearly entire dorsal margin of the leaf. This species is described and illustrated in detail, and its diagnostic characters and a comparison with the related species are briefly treated.
\end{abstract}

Key words: Colura, diversity, elater pattern, liverwort, Thailand

Jiroat Sangrattanaprasert \& Sahut Chantanaorrapint, Department of Biology, Faculty of Science, Prince of Songkla University, Hai Yai, Songkhla, 90112 Thailand; e-mail: chantanaorrapint@gmail.com

Rui-Liang Zhu, Department of Biology, School of Life Sciences, East China Normal University, 3663 Zhong Shan Road, Shanghai 200062, China; e-mail: rlzhu@bio.ecnu.edu.cn

\section{INTRODUCTION}

The genus Colura was proposed as a section of Jungermannia L. (Dumortier 1831) and was subsequently raised to generic rank by Dumortier (1835) based on C. calyptrifolia (Hook.) Dumort. This genus belongs to Lejeuneaceae, which is the largest family of the liverworts (Gradstein 2013) and contains ca 83 currently accepted species (Söderström et al. 2016), of which 39 are endemic (Pócs 1996; Frey \& Stech 2009). Most species of the genus are small and epiphyllous in habit, but some species occur on tree trunks and branches. The genus Colura is easily separated from other genera by (i) having one deeply bilobed underleaf for each lateral leaf, ( $i i)$ the presence of tubular to cylindrical leaf lobules usually broadening distally and terminating in a sac, and (iii) the presence of a valve and pore in the sac. The genus is distributed mainly in tropical and subtropical regions (Pócs 1996; Zhu \& So 2001; Frey \& Stech 2009), with a hotspot in the Malesian region (Pócs 1996). There are floristic reports of

\footnotetext{
1 Corresponding author
}

Colura species from parts of the Malesian region, such as the Philippines and Borneo (Tan \& Engel 1986), Java (Söderström et al. 2010), Malaysia (Kitagawa 1969; Chuah-Petiot 2011) and Thailand (Jovet-Ast 1967a; Lai et al. 2008; Sukkharak et al. 2008; Chantanaorrapint \& Pócs 2014; Pócs \& Podani 2015). However, some Colura species are rarely reported and have been collected only once or a few times.

During a revision of the genus Colura in the Malesian region, some interesting specimens were found at the summit of Khao Chedyod Mt. in southern Thailand. After a careful examination, the unknown collections were identified as Colura crenulata Grolle, a little-known species first described by Grolle (1965) based on a specimen collected by M. S. Clemens in Morobe Province, Papua New Guinea, and subsequently reported by Jovet-Ast (1967b) from Sumatra, Indonesia and Sabah, Malaysia. This is the third report of the species and the first one from Thailand. The following description and illustrations are based on the recent specimens from Thailand. In addition, 
the sporophytes of Colura crenulata are described in detail for the first time.

\section{DESCRIPTION}

\section{Colura crenulata Grolle}

Figs $1 \& 2$

J. Hattori Bot. Lab. 28: 46. 1965

Type: PAPUA NEW GUINEA. Morobe: Yunzaing, 1500-1800 m, 1936, M.S. Clemens 3817/H-b (HOLOTYPE: B).

Plants pale green, $0.3-1.0 \mathrm{~cm}$ long; shoots $1.2-2.5 \mathrm{~mm}$ wide; irregularly pinnately branched, branches Lejeunea-type. Stem 100-137 $\mu \mathrm{m}$ in diameter, in transverse section consisting of 7 cortical cells $(37-63 \times 27-48 \mu \mathrm{m})$ and 3 medullary cells $(25-38 \times 20-28 \mu \mathrm{m})$; ventral merophytes of stem 2 cells wide. Rhizoids numerous, fasciculate at base of underleaves. Leaves contiguous to imbricate, spreading from stem at $0^{\circ}-70^{\circ}$ angle. Lobes 0.75-1.45 mm long, 0.40-0.75 mm wide; dorsal margin \pm plane, entire to crenulate. Lobe cells thin-walled, trigones large, intermediate thickenings very distinct; marginal cells isodiametric to slightly rectangular or subquadrate, $25-45 \times$ 25-35 $\mu \mathrm{m}$; median cells rectangular, isodiametric to hexagonal, $32-63 \times 22-38 \mu \mathrm{m}$; basal cells rectangular to hexagonal, 37-63 × 20-45 $\mu \mathrm{m}$. Cuticle smooth. Oil bodies 14-20 per cell, homogenous, ellipsoid, 4-8 × 1.6-3.2 $\mu \mathrm{m}$. Lobules narrowly tubular, flaring toward sac, 1.35-2.25 mm long. Lobule sac elliptic, strongly inflated, 0.6-1.9 mm long, $0.50-0.65 \mathrm{~mm}$ wide, sac surface conicalmamillose, apex acute, ending in lamellar crista consisting of 1-5 cells. Valves complex-type, elliptic, broadly ovate to slightly round, 114-144 $\times$ 94-124 $\mu \mathrm{m}$, composed of one circle of 18-21 hyaline marginal and 20-29 median cells with one basal median cell. Hyaline papilla spherical, $15-20 \mu \mathrm{m}$ in diameter. Valve frame outline semicircular with cell triseriate, $c a 182 \mu \mathrm{m}$ wide; cell wall entire to slightly undulate. Underleaves distant, deeply bilobed, sinus obtuse; lobe lanceolate, $150-200 \times 55-115 \mu \mathrm{m}, 6-7$ cells long, 4-5 cells wide at base; margin entire.

Dioicous. Androecia lateral or intermediate on main stem and branch; male bracts hemispherical, apical keel crenulate with one projecting cell row, free margin entire, in 2-7 pairs; bract lobes oblong to semicircular, $230-300 \times 160-185 \mu \mathrm{m}$; bract lobules semicircular, 220-290 × 145-185 $\mu \mathrm{m}$, bract lobules as large as bract lobes. Antheridia 2 per bract; male bracteoles bilobed to round, small, few-celled. Gynoecia terminal on lateral branch; female bracts ovate to elliptic; bract lobes oblong to elliptic, $750-900 \times 250-450 \mu \mathrm{m}$; bract lobules narrowly oblong, 750-800 × 150-200 $\mu \mathrm{m}$; female bracteole similar to underleaf, 125-250 $\times 37-88 \mu \mathrm{m}$. Perianth obovate to obtriangular, 1.35-1.50 mm long, 0.45-0.75 mm wide, with 3 keels; keels oblique-triangular or horn-like, 250-300 × 170-220 $\mu \mathrm{m}$, spreading horizontally, bearing a coarse tooth near its apex; surface of perianth strongly mamillose; beak $1-3$ cells long. Sporophyte. Seta articulate, 8-9 cells long, upon elongation to $1.5-2.0 \mathrm{~mm}$ long. Capsule spherical, $325-360 \mu \mathrm{m}$ in diameter, splitting $\pm 2 / 3$ its length into four erect valves after dehiscence; capsule valve $360-370 \times 230-240 \mu \mathrm{m}$, wall $2-3$ stratose, hyaline. Outer layer capsule valve apex formed by one quadrate cell; cell of upper half of valve rhombic, large, thin-walled; hinge butterflyshaped, hinge cells rectangular to quadrate, smaller than upper-half cells, thin-walled; marginal cells rectangular, formed by 1-2 rows. Inner layer capsule valve cells in center rectangular, walls with nodular thickenings; marginal cells of upper half quadrate, walls nodulose, formed by $1-2$ rows, marginal cells of lower half rectangular, walls smooth. Elaters of two types: marginal and additional; marginal elaters 22 per capsule, each valve containing 4 or 5 upper marginal elaters and 2 or no lower marginal elaters; upper marginal elaters attached to upper half of valve margin by one end, 220-305 $\mu \mathrm{m}$ long, 16-20 $\mu \mathrm{m}$ wide, hyaline to yellowish, with irregular thickening, end attached to valve margin rounded, not expanded, free end dilated; lower marginal elaters attached to valve at both ends (near and parallel to basal margin), ca $200 \mu \mathrm{m}$ long, $20 \mu \mathrm{m}$ wide, hyaline, with irregular to annular thickening, upper end narrowly tapered, lower end obtuse; additional elaters 4 per capsule ( 1 per each valve), $280-310 \mu \mathrm{m}$ long, ca $10 \mu \mathrm{m}$ wide, hyaline, with smooth thickening, 

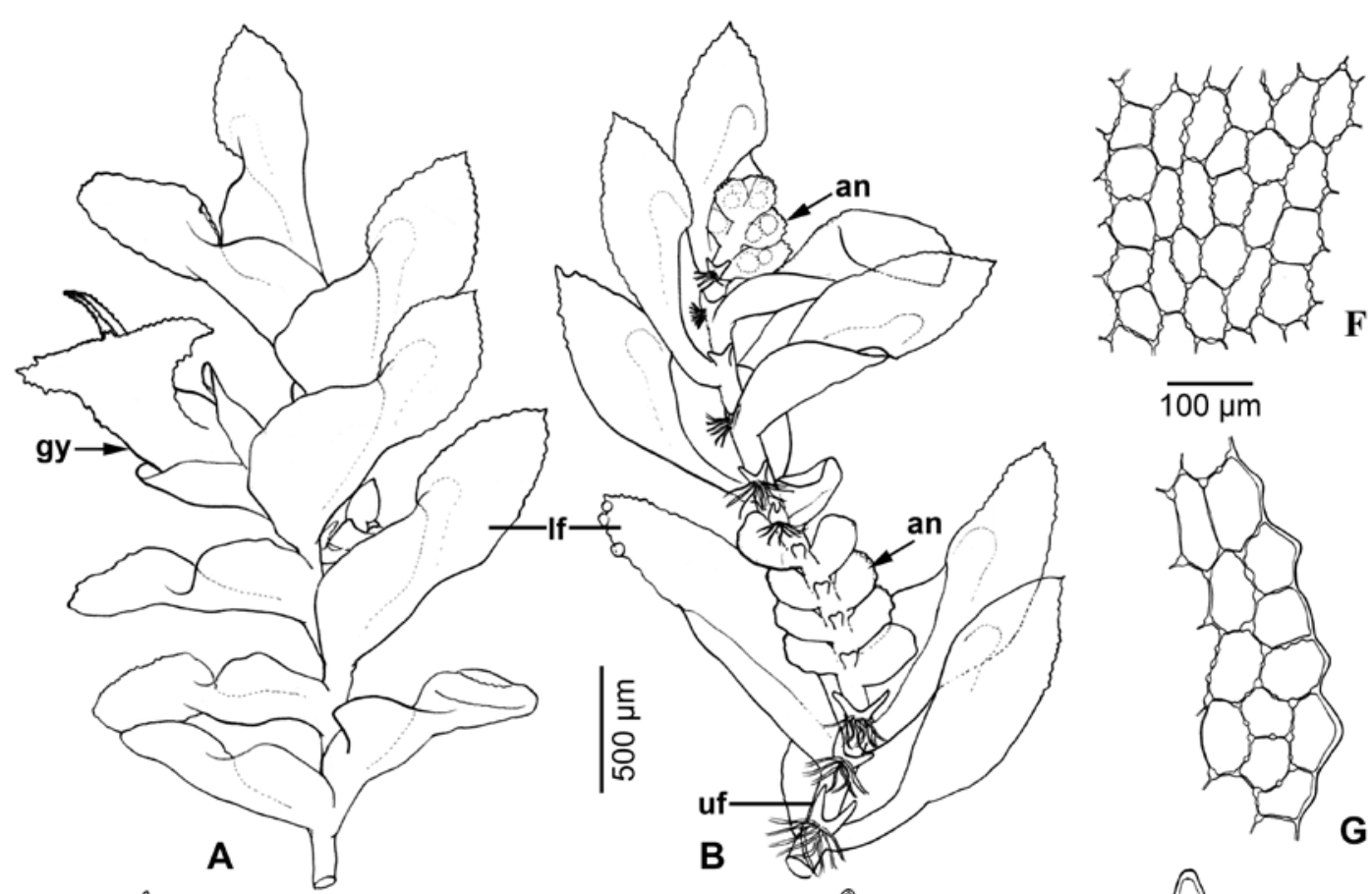

\section{$\overline{100 \mu \mathrm{m}}$}
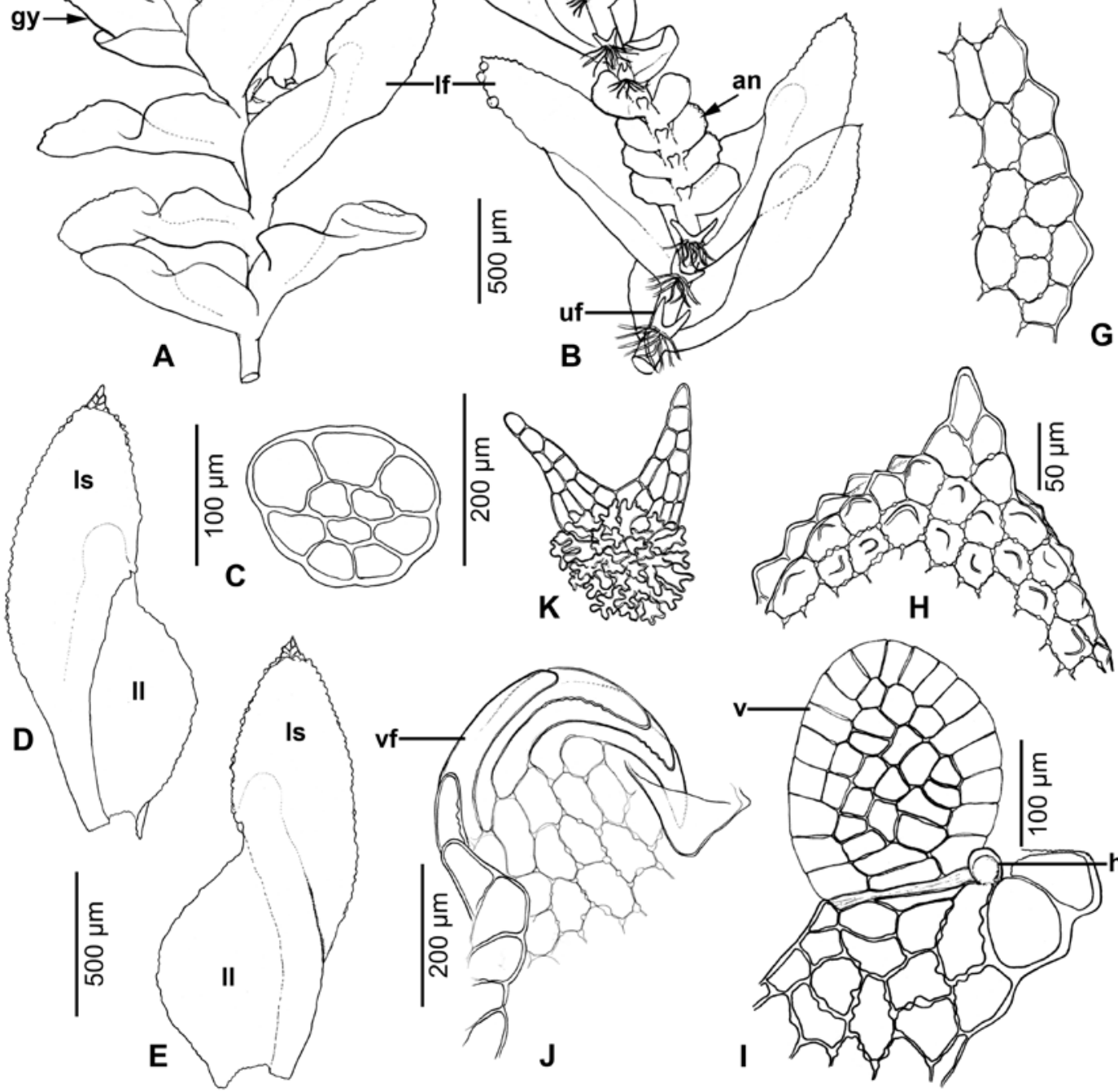

Fig. 1. Colura crenulata Grolle. A - portion of plant with gynoecium (gy), dorsal view; B - portion of plant with androecia (an), ventral view; C - stem in transverse section; D \& E - lateral leaf (lf) consisting of leaf lobe (11) and lobule sac (1s): D - ventral view, E - dorsal view; F \& G - leaf lobe cells: F - median cells, G - marginal cells; H - crest and mamillae on apex of lobule sac; I - valve (v) and hyaline papilla (h); J - valve frame (vf); K - underleaf (uf). All from J. Sangrattanaprasert 138/14B (PSU). 

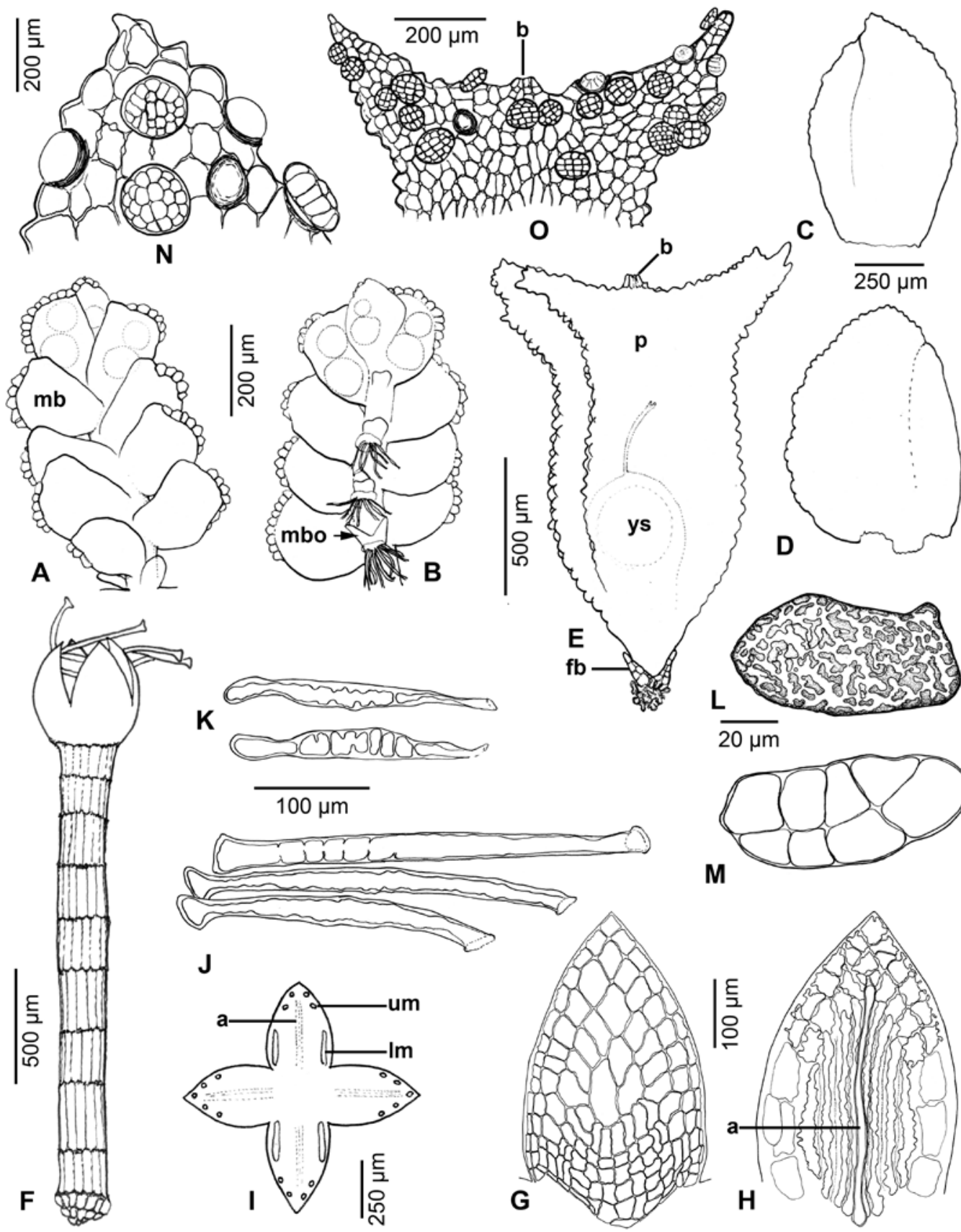

Fig. 2. Colura crenulata. A \& B - androecia: A - dorsal view showing male bracts (mb), B - ventral view showing male bracteoles (mbo); C \& D - female bract: C - dorsal view, D - ventral view; E - perianth (p) with female bracteole (fb) (b-beak of perianth, ys - young sporophyte); F - mature sporophyte; $\mathrm{G}$ - outer layer valve; $\mathrm{H}$ - inner layer valve; I - scheme of elater distribution ( $\mathrm{a}$ - additional elater, $\mathrm{lm}$ - lower marginal elater, um - upper marginal elater); $\mathrm{J}$ - upper marginal elaters; $\mathrm{K}$ - lower marginal elaters; $\mathrm{L}$ - spore; $\mathrm{M}$ - spore showing cylindrical protonema; $\mathrm{N} \& \mathrm{O}$ - gemmae: $\mathrm{N}$ - occurring on lobule sac apex, $\mathrm{O}$ - occurring on perianth keel apex. All from J. Sangrattanaprasert 138/14B (PSU). 
attached along their whole length to median part of valve, even upon dehiscence. Spores green, irregular-oblong or elongate-rectangular, 54-88 $\times 28-35 \mu \mathrm{m}$; spore surface covered with irregular lamellae; sporeling Lejeunea-type. Asexual reproduction by discoid gemmae, occurring on lobule sac apex and sometimes on perianth apex.

Habitat AND ECOLOGY. Colura crenulata occurs on living leaves and twigs of shrubs and small trees in tropical montane forest at 1,000 to $1,100 \mathrm{~m}$ a.s.1. The species was associated with other epiphyllous liverworts such as Ceratolejeunea belangeriana (Gottsche) Steph., Cheilolejeunea trapezia (Nees) R. M. Schust. \& Kachroo, Drepanolejeunea spp. and Metalejeunea cucullata (Reinw. et al.) Grolle.

Distribution. Indonesia (West Sumatra), Malaysia (Sabah), New Guinea (Morobe), and new to Thailand.

Specimens examined. INDONESIA. West SuMATRA: Mt. Tandikat, ca 1000 m, 23 July 1955, W. Meijer $8077 c$ (L). MALAYSIA. NORTH BORNEO: Mt. Tambuyokon, c. 15 miles NE. of Kinabalu Peak, 1800-2100 m, 6 July 1961, W. Meijer B 11210 (L). THAILAND. Trang Province: Palian District, Khao Chedyod, 1040-1070 m, 07¹9'18.80"N, 99 54'40.48"E, 3 May 2014. J. Sangrattanaprasert 115/14C, 138/14B, 140/14B (HSNU, PSU).

TAXONOMIC NOTES. Colura crenulata is easily recognized by $(i)$ the rather large plant, with leaves 0.6-1.1 mm wide, (ii) the large elliptic lobule sac, (iii) the strongly mamillose surface of the lobule sac and perianth, (vi) the presence of the lamina projecting to the lobule sac apex, and $(v)$ the entire dorsal margin of the leaf lobule.

Colura crenulata is morphologically similar to $C$. thomeensis Pócs, C. herzogii Jovet-Ast and C. conica (Sande Lac.) K. I. Goebel. The four species belong to subgenus Colura, section Harmophyllum Grolle, and share many similar characteristics in underleaf form, valve type, surface lobule sac and perianth, the presence of the apical crest of the lobule sac, and other characters. Colura thomeensis, an endemic species from Saõ Tomé Island (Pócs 2011), is distinguished from C. crenulata by its large apical crest of the lobule sac consisting of 7-15 cells, and a small valve composed of 12-13 hyaline marginal cells and 6-8 median cells. Colura conica, a common species in tropical and subtropical Asia (Zhu \& So 2001), is distinguished from $C$. crenulata by the dentate dorsal margin of leaf the lobes, the valve consisting 13-18 median cells (with 1-2 basal cells) and one circle of 14-17 hyaline marginal cells, and the perianth with (3-)4(-5) keels. Colura herzogii, a Malesian species (Jovet-Ast 1953), differs from C. crenulata in having 1-2 basal median cells of the valve and an irregularly dentate dorsal leaf margin. Pócs (2013) also noted that $C$. crenulata is quite similar to Colura fastigiata Jovet-Ast, an endemic species from Cambodia (Jovet-Ast 1958), but the latter differs from $C$. crenulata in having 2 basal median cells of the valve and a strongly dentate dorsal margin of the leaf lobe.

The sporophyte characters of Colura crenulata are similar to other members of the genus in having an articulate seta, dehiscence of a spherical capsule into four valves, and the elaters attached to the upper half margin of the inner side of the valve (Jovet-Ast 1953). We also studied the elaters of the following species: C. herzogii, C. imperfecta Steph., C. karstenii K. I. Goebel, C. meijeri Jovet-Ast, C. speciosa Jovet-Ast and C. verdoornii Herzog \& Jovet-Ast. The two types of elaters are similar within the eight species: 22 marginal elaters (18 upper and 4 lower), plus additional elaters. The additional elaters might be confused with the median cells of the inner wall of the valve, which is somewhat elongatedrectangular with nodular thickenings. For a better understanding of the elater pattern of the genus, more species need to be investigated.

ACKNOWLEDGEMENTS. We thank the curators of BM, BO, EGR, HSNU and L for making specimens including types available for study through loans or visits, and Dr. Alfons Schäfer-Verwimp (Germany) and Dr. D. Christine Cargill (Australia) for helpful remarks and suggestions on the manuscript. This work was financially supported by the Graduate School of Prince of Songkla University and by the National Natural Science Foundation of China (no. 31370238 and no. 31570206). Funding by the Science Achievement Scholarship of Thailand (SAST) is gratefully acknowledged by the first author. 


\section{REFERENCES}

Chantanaorrapint S. \& Pócs T. 2014. Southern Thailand bryophytes I, with description of Cololejeunea ramromensis. In: D. Telnov (ed.), Biodiversity, Biogeography and Nature Conservation in Wallacea and New Guinea, II. pp. 113-122. Rīga, the Entomological society of Latvia.

Chunh-Petiot M. S. 2011. A checklist of Hepaticae and Anthocerotae of Malaysia. Polish Bot. J. 56: 1-44.

Dumortier B. C. J. 1831. Sylloge Jungermannidearum Europae Indigenerum. Tornaci Nerviorum, typis J. Casterman.

Dumortier B. C. J. 1835. Recueil observation Jungermanniacées, Fascicule I. - Révision des genres. pp. 1-27. Imprimerie De J.-A. Blanquart., Tournay.

Frey W. \& Stech M. 2009. Marchantiophyta, Bryophyta, Anthocerotophyta. In: W. FreY (ed.), Syllabus of Plant Families. A. Engler's Syllabus der Pflanzenfamilien, Part 3. Bryophytes and seedless Vascular Plants. Ed. 13, pp. 9-263. Druckerei Strauss GmbH, Mörlenbach.

Gradstein S. R. 2013. A classification of Lejeuneaceae (Marchantiophyta) based on molecular and morphological evidence. Phytotaxa 100: 6-20.

Grolle R. 1965. Lebermoose aus Neuguinea. I. J. Hattori Bot. Lab. 28: 43-54.

Jovet-Ast S. 1953. Le genre Colura, Hépatiques, Lejeuneacées, Diplasiae. Rev. Bryol. Lichénol. N. Sér. 22: 206-312.

Jovet-Ast S. 1958. Hépatiques du Cambodge récoltées par le Professeur Roger Heim. Rev. Bryol. Lichénol. N. Sér. 27: 24-30.

Jovet-Ast S. 1967a. Colura récoltés du Pakistan aux Philippnes par Pierre Tixier. Rev. Bryol. Lichénol. N. Sér 35: 138-142.

Jovet-Ast S. 1967b. Compléments à l'étude des Colura: localités nouvelles; description d'une espèce nouvelle de Bornéo. Rev. Bryol. Lichénol. N. Sér. 35: 143-148.

Kitagawa N. 1969. A small collection of Hepaticae from Penang, Malaysia. Bulletin of Nara University of Education 18: $27-43$.

Lai M.-J., Zhu R.-L. \& Chantanaorrapint S. 2008. Liverworts and hornworts of Thailand: an updated checklist and bryofloristic accounts. Ann. Bot. Fenn. 45: 321-341.
Pócs T. 1996. Epiphyllous liverwort diversity at worldwide level and its threat and conservation. Anales Inst. Biol. Univ. Nac. Autón. México, Bot. 67: 109-127.

Pócs T. 2011. New or little known epiphyllous liverworts, XIV. The genus Colura (Lejeuneaceae) in São Tomé Island, with the description of Colura thomeensis sp. nov. Bryologist 114: $362-366$.

Pócs T. 2013. The genus Colura (Lejeuneaceae) in New Guinea and in the neighboring areas. Chenia 11: 12-38.

Pócs T. \& PODANI J. 2015. Southern Thailand bryophytes II. Epiphylls from the Phang-Nga area. Acta Bot. Hung. 57: 183-198.

SöDERSTRÖM L., Gradstein S. R. \& HaGborG A. 2010. Checklist of the hornworts and liverworts of Java. Phytotaxa 9: 53-149.

Söderström L., Hagborg A., Von Konrat M., Bartholomew-Began S., Bell D., Briscoe L., Brown E., Cargill D. C., Costa D. P., Crandall-Stotler B. J., Cooper E. D., Dauphin G., Engel J. J., Feldberg K., Glenny D., Gradstein S. R., He X., Heinrichs J., Hentschel J., Ilkiu-Borges A. L., Katagiri T., Konstantinova N. A., Larraín J., Long D. G., Nebel M., Pócs T., Puche F., Reiner-Drehwald E., Renner M. A. M., Sass-Gyarmati A., Schäfer-Verwimp A., Segarra Moragues J. G., Stotler R. E., Sukkharak P., Thiers B. M., Uribe J., Váña J., Villarreal J. C., Wigginton M., Zhang L. \& ZHU R.-L. 2016. World checklist of hornworts and liverworts. PhytoKeys 59: 1-828.

Sukkharak P., Seelanan T. \& Lai M.-J. 2008. Liverwort diversity at the summit of Khao Nan, Khao Nan National Park, Nakhon Si Thammarat Province. In: H. MoHAmed, B. B. BAKer, A. N. Boyce \& P. K.Y. Lee (eds), Bryology in the New Millennium, pp. 49-55. Kuala Lampur, University of Malaya.

Tan B. C. \& Engel J. J. 1986. An Annotated Checklist of Philippine Hepaticae. J. Hattori Bot. Lab. 60: 283-355.

ZHU R.-L. \& So M. L. 2001. Epiphyllous Liverworts of China. Nova Hedwigia Beih. 121: 1-418. 